This article was downloaded by: [BOSE - Ozone: Science \& Engineering]

On: 4 August 2008

Access details: Access Details: [subscription number 768277076]

Publisher Taylor \& Francis

Informa Ltd Registered in England and Wales Registered Number: 1072954 Registered office: Mortimer House, 37-41 Mortimer Street, London W1T 3JH, UK

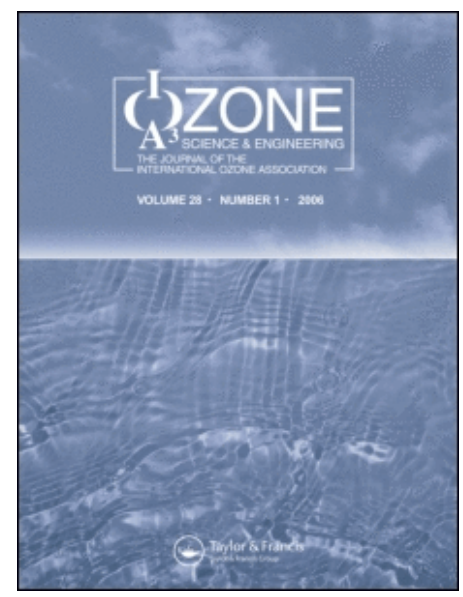

Ozone: Science \& Engineering

Publication details, including instructions for authors and subscription information:

http://www.informaworld.com/smpp/title content=t713610645

\title{
The Impact of Traces of Hydrogen Peroxide and Phosphate on the Ozone Decomposition Rate in "Pure Water"
}

K. Vandersmissen a; F. De Smedt a; C. Vinckier ${ }^{a}$

a KULeuven, Department of Chemistry, Laboratory for Physical and Analytical Chemistry, Leuven, Belgium

Online Publication Date: 01 July 2008

To cite this Article Vandersmissen, K., De Smedt, F. and Vinckier, C.(2008)'The Impact of Traces of Hydrogen Peroxide and Phosphate on the Ozone Decomposition Rate in "Pure Water"',Ozone: Science \& Engineering,30:4,300 - 309

To link to this Article: DOI: $10.1080 / 01919510802144085$

URL: http://dx.doi.org/10.1080/01919510802144085

\section{PLEASE SCROLL DOWN FOR ARTICLE}

Full terms and conditions of use: http://www.informaworld.com/terms-and-conditions-of-access.pdf

This article may be used for research, teaching and private study purposes. Any substantial or

systematic reproduction, re-distribution, re-selling, loan or sub-licensing, systematic supply or distribution in any form to anyone is expressly forbidden.

The publisher does not give any warranty express or implied or make any representation that the contents will be complete or accurate or up to date. The accuracy of any instructions, formulae and drug doses should be independently verified with primary sources. The publisher shall not be liable for any loss, actions, claims, proceedings, demand or costs or damages whatsoever or howsoever caused arising directly or indirectly in connection with or arising out of the use of this material. 


\title{
The Impact of Traces of Hydrogen Peroxide and Phosphate on the Ozone Decomposition Rate in "Pure Water"
}

\author{
K. Vandersmissen, F. De Smedt, and C. Vinckier \\ KULeuven, Department of Chemistry, Laboratory for Physical and Analytical Chemistry, Leuven, Belgium
}

\begin{abstract}
To obtain an idea of the magnitudes of the ozone loss rates $r_{O_{3}}$ in practical applications of ozone, an overall determination of the ozone decay profiles and rate constants was carried out in four different systems. These systems resemble different conditions for industrial application of ozone and the peroxone process, such as in the field of micro electronics, drinking water purification, disinfection, etc. Therefore, the behavior of ozone was monitored in the $\mathrm{pH}$ range from 4.5 to 9.0, in pure water and phosphate buffered systems in absence and presence of small amounts of hydrogen peroxide $\left(10^{-7} \mathrm{M}\right.$ to $\left.10^{-5} \mathrm{M} \mathrm{H}_{2} \mathrm{O}_{2}\right)$. First the reproducibility of the ozone decay profiles was checked and from the various kinetic formalism tests, the reaction order 1.5 for the ozone decay rate has been selected. As expected, hydrogen peroxide increases the decay rates. In pure systems, added concentrations of $10^{-7} \mathrm{M} \mathrm{H}_{2} \mathrm{O}_{2}$ already cause a remarkable acceleration of the ozone decay in the acidic and neutral $\mathrm{pH}$ range compared to the pure systems. However for alkaline $\mathrm{pH}$ conditions almost no effect of the low hydrogen peroxide concentrations was noticed. Contradictory to literature data, in the absence of hydrogen peroxide, ozone displays faster decays in the buffered systems of low ionic strength of 0.02 compared to pure water. This acceleration is more pronounced for acidic pH conditions. Low concentrations of phosphate may indeed accelerate the ozone decay in the presence of organic matter. Adding $\mathrm{H}_{2} \mathrm{O}_{2}$ concentrations below $10^{-5} \mathrm{M}$ to phosphate buffered solutions has a negligible effect on the ozone decay rate compared with pure water systems, except for $\mathrm{pH}$ 7. It appears that phosphate masks the effect of hydrogen peroxide below $10^{-5} \mathrm{M}$ as tested here. Thus the application of AOP's by adding low concentrations of hydrogen peroxide is not well feasible in the presence of phosphate buffers in pure water systems.
\end{abstract}

Keywords Ozone, Reaction Kinetics, Hydrogen Peroxide, Phosphate, Advanced Oxidation Processes

Received 10/24/2007; Accepted 4/9/2007

Address correspondence to K. Vandersmissen, KULeuven, Department of Chemistry, Laboratory for Physical and Analytical Chemistry, Celestijnenlaan 200F, 3001 Leuven, Belgium. E-mail: chris.vinckier@chem.kuleuven.be

\section{INTRODUCTION}

For several decades, ozone has been, and still is, used in a wide range of industrial applications (Kruithof and Masschelein, 1999; Lowndes, 1999; Matsumoto et al., 1999), from paper bleaching over micro-electronics to waste and drinking water purification and disinfection. These processes are based upon the direct reaction of ozone with DOM (dissolved organic mater) and other compounds, the so-called "direct oxidation." But not all pollutants can be well oxidized and destroyed by ozone. Therefore "indirect oxidation" by radicals, mainly focused on the hydroxyl radical, also has to be taken into account. The hydroxyl radical being a very powerful oxidant is of great importance in these processes. It is known to react rapidly and unselectively with a large number of organic pollutants.

Indirect oxidation can be enhanced by realizing higher radical concentrations for the same ozone concentration. One possibility to increase the total radical concentration (RP; radical pool) relative to ozone is the peroxone process, where $\mathrm{H}_{2} \mathrm{O}_{2}$ is added to an ozone containing solution. Hydrogen peroxide initiates the ozone decomposition and accelerates the decay and thus generates extra radicals (Staehelin and Hoigne, 1985).

The direct and indirect oxidation reactions compete for substrate (i.e., compounds to oxidize). The rate constants of direct oxidation with molecular ozone is relatively slow $\left(10^{-5}-10^{2} \mathrm{M}^{-1} \mathrm{~s}^{-1}\right.$ ) (Hoigne and Bader, 1983a, 1983b; Hoigne et al., 1985), except for olefins and aromatic compounds, compared to hydroxyl radical oxidation $\left(10^{3}-10^{11} \mathrm{M}^{-1} \mathrm{~s}^{-1}\right)$ (Weinstein and Bielski, 1979; Buxton et al., 1988; Alfassi et al., 1992; Stemmler and von Gunten, 2000), but the concentration of ozone is of course always much larger than the hydroxyl radical concentration.

As with ozone alone, $\mathrm{pH}$ and bicarbonate alkalinity play a major role in the peroxone effectiveness (Glaze et al., 1987). The role is primarily related to bicarbonate 
and carbonate competition (Acero and von Gunten, 2000; Elovitz et al., 2000) for the hydroxyl radical at high alkalinity and high $\mathrm{pH}$ levels. In several industrial applications it is necessary to work in as "clean" or "pure" systems as possible, for example in the field of micro electronics, food industry and disinfection systems. Therefore, it was thrived in this work, to avoid as much additives as possible in order to distort the systems as little as possible. Low phosphate buffer concentrations were used and only hydrogen peroxide concentrations below $10^{-5} \mathrm{M}$ were tested.

By adding hydrogen peroxide to the water, the ozone transfer from gas phase to liquid phase can be improved due to an increase in ozone reaction rates. The AOP (Advanced Oxidation Process) ozone-hydrogen peroxide is a common used purification treatment (Perkowski et al., 2000; Loeb, 2002) for ground water and surface water contaminated with refractory compounds. When ozone and peroxone processes are compared one sees an advantage for ozone, due to its electrophylic character, regarding oxidizing compounds with double bounds, iron and manganese and for its disinfection ability. Disinfection can also be realized by the peroxone process, but it is certainly favored when taste and odor compounds have to be removed and in any case for the degradation of persistent organic pollutants (POPs).

Sehested et al. (1998) investigated the $\mathrm{O}_{3}$ decay in acidic solutions with and without hydrogen peroxide. $\mathrm{He}$ postulates the formation of significant amounts of hydrogen peroxide $\left(10^{-6} \mathrm{M}\right)$ during the ozone decomposition and argues that termination also has to occur through impurities to explain the slower than expected ozone decay rate. This concentration of formed hydrogen peroxide is independent of the initial ozone concentration or the $\mathrm{pH}$, but only dependent of the temperature: more hydrogen peroxide is formed at higher temperature. Also Staehelin and Hoigné (1982) propose the presence of hydrogen peroxide as an important intermediate product from the ozonolysis of aqueous solutions. This $\mathrm{H}_{2} \mathrm{O}_{2}$ formation results either directly from $\mathrm{O}_{3}$ decomposition through $\mathrm{O}_{3}+\mathrm{OH}^{-} \rightarrow \mathrm{O}_{2}+\mathrm{HO}_{2}^{-}$or from the hydrolysis of organic ozonation products. They observed that the hydrogen peroxide formed in this way enhances the $\mathrm{O}_{3}$ decomposition rate.

To determine the magnitude of the ozone loss rates $\mathrm{r}_{\mathrm{O}_{3}}$, an extensive study was carried out on the ozone decay rate in several dilute aqueous systems. $\mathrm{R}_{\mathrm{O} 3}$ is an essential variable to calculate maximum achievable ozone concentrations in solutions $\left[\mathrm{O}_{3}\right]_{\mathrm{liq}, \mathrm{ss}}$ : Eq. [1]. This concentration is indeed dependent on the maximum achievable ozone concentration $\left[\mathrm{O}_{3}\right]^{*}{ }_{\text {liq }}=\mathrm{H} \times \mathrm{P}_{\mathrm{O}_{3}}$ according to Henry's Law, the mass transfer coefficient $\mathrm{k}_{\mathrm{L}}$ a and $\mathrm{r}_{\mathrm{O}_{3}}$. $\left[\mathrm{O}_{3}\right]^{*}{ }_{\text {liq }}$ is determined by the value of the Henry's Law constant $\mathrm{H}$ and the partial pressure of the ozone gas $\mathrm{P}_{\mathrm{O}_{3}}$. The magnitude of the two variables $\mathrm{P}_{\mathrm{O}_{3}}$ and $\mathrm{k}_{\mathrm{L}}$ a is dependent on the systems design and setup. However the ozone loss rate is determined by the physical and chemical properties of the system.

$$
\left[O_{3}\right]_{l i q, s s}=\left[O_{3}\right]_{l i q}^{*}-\frac{r_{O_{3}}}{k_{L} a}=H \times P_{O_{3}}-\frac{r_{O_{3}}}{k_{L} a}
$$

In this work the determination of $\mathrm{r}_{\mathrm{O} 3}$ by several mathematical formalisms will be discussed. Furthermore the influence of the addition of low phosphate and hydrogen concentrations will be investigated and quantified.

\section{EXPERIMENTAL}

\section{Experimental Setup}

The set-up is presented in Figure 1. Ozone solutions were prepared by leading an ozone/oxygen gas stream, transferred by a porous diffuser, into a MilliQ water solution $(<18 \mathrm{M} \Omega$ resistivity) in a 2-liter glass vessel. TOC and TIC analysis of the process water, before, during and after ozonation, gave results below detection limits of $1 \mathrm{ppm}$ carbon. The aqueous solution was kept at a constant temperature of $298 \mathrm{~K}$. Ozone was generated by a corona discharge ozone generator (Fisher 500, Pittsburgh, PA) using $\mathrm{O}_{2}$ (Praxair 5.0, Danbury, CT) as feed gas. The flow of $\mathrm{O}_{2}$ was controlled with a Brooks Mass Flow Controller Model 5850E (Hatfield, PA). The ozone concentrations in the gas streams and in solution were variable between respectively 28 and $63 \mathrm{~g} / \mathrm{m}^{3}$ and 1.4 and $2.6 \times 10^{-4} \mathrm{M}$.

The produced ozone gas concentrations were monitored by an ozone sensor IN USA model gFFOZ (Needham, MA), based upon the absorbance of ozone in the gas phase at $254 \mathrm{~nm}$. Samples of the ozonated water were withdrawn from the vessel by a peristaltic pump. The ozone liquid steady-state concentration was determined with an electrochemical sensor Orbisphere 313 and Model 3600 Analyzer of Orbisphere (Geneva, Switzerland). All tubing is made up of the $\mathrm{O}_{3}$-resistent FEP polymer.

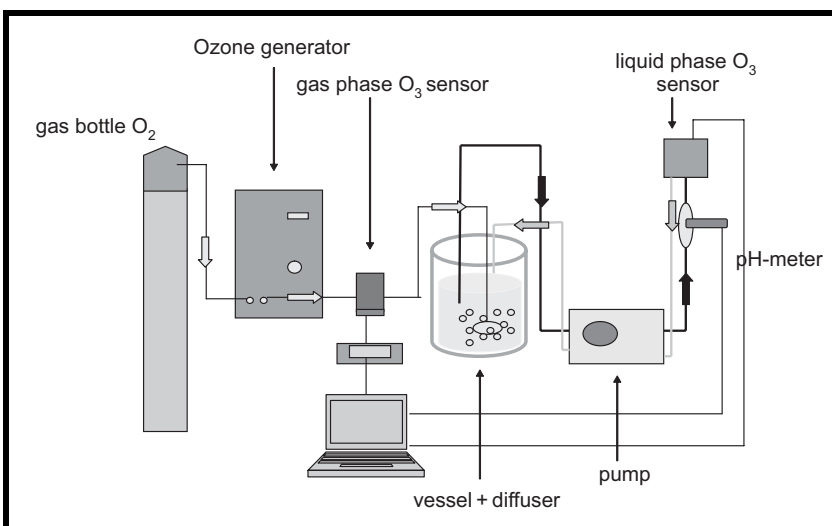

FIGURE 1. Schematic overview of experimental setup. 
The $\mathrm{pH}$ of the ozone solution was adjusted with $\mathrm{HNO}_{3}$ and $\mathrm{NaOH}$, both of p.a. quality. These chemicals are known not to act as radical inhibitors or promoters concerning the ozone decomposition. $\mathrm{pHs}$ ranging from 4.5 up to 9 were tested for the non-buffered systems and the $\mathrm{pH}$ was continuously measured with a $\mathrm{pH}$ meter. Buffered solutions were prepared with p.a. quality sodium dihydrogen phosphate and dipotassium hydrogen phosphate (Riedel-de Haën, Hanover, Germany). The concentrations were kept low to eliminate, as much as possible, the influence of the ionic strength and phosphate components, but still high enough to maintain steady $\mathrm{pH}$ values. $\mathrm{O}_{3}$ decays at three different $\mathrm{pH}$ values $4.5,7.0$ and 9.0 were monitored, with buffer concentrations of $0.01 \mathrm{M}$ for $\mathrm{pH} 7$ and 9 and $0.02 \mathrm{M}$ for $\mathrm{pH} 4.5$. Stock solutions of hydrogen peroxide were made with $35 \%$ p.a. quality $\mathrm{H}_{2} \mathrm{O}_{2}$ (Chem-Lab) and renewed every day to avoid deviation of calculated hydrogen peroxide concentrations due to UV/VIS irradiation or temperature degradation. Concentrations of hydrogen peroxide ranging from $10^{-5} \mathrm{M}$ to $10^{-7} \mathrm{M}$ were tested.

\section{EXPERIMENTAL METHOD}

When the ozone steady-state concentration was reached in the vessel, then a sample of $3.7 \mathrm{ml}$ was taken from the vessel and put into a cuvette for measuring the ozone decay profiles by a spectrophotometer. Ozone was followed by its UV absorbance at $260 \mathrm{~nm}$ (with its molar extinction coefficient $\epsilon=3000 \mathrm{M}^{-1}$ ) for over two halflife times using a Shimadzu spectrophotometer (Kyoto, Japan). To test the effect of hydrogen peroxide, it was decided to only add the promoter to the sample and not to the whole ozone stock solution. The mixing of hydrogen peroxide and the ozone containing solutions was carried out directly in the cuvette and the ozone decay was monitored immediately after mixing.

\section{Kinetic Analysis}

The ozone decay rate $\left(\mathrm{r}_{\mathrm{O}_{3}}=-\mathrm{d}\left[\mathrm{O}_{3}\right]_{\text {liq }} / \mathrm{dt}\right)$ can be described as function of the ozone concentration in the liquid phase $\left[\mathrm{O}_{3}\right]_{\text {liq }}$ with a reaction order $\mathrm{n}$ and the hydroxyl ion concentration $\left[\mathrm{OH}^{-}\right]$with reaction order $\mathrm{m}$ and a rate constant $\mathrm{k}_{\mathrm{n}}{ }^{\prime}$ Eq. [2] This expression has the advantage that the $\mathrm{pH}$ effect on $\mathrm{r}_{\mathrm{O}_{3}}$ is directly quantified. However in many experimental studies a more simple expression is often used with an overall rate constant $\mathrm{k}_{\mathrm{n}}$ and a reaction order $\mathrm{n}$ :

$$
-\frac{d\left[O_{3}\right]_{l i q}}{d t}=k_{n}^{\prime}\left[O_{3}\right]_{l i q}^{n}\left[O H^{-}\right]^{m}=k_{n}\left[O_{3}\right]_{l i q}^{n}=r_{O_{3}}
$$

with $\mathrm{k}_{\mathrm{n}}$ the $\mathrm{n}^{\text {th }}$-order rate constant. For comparable ozone concentrations, higher $\mathrm{r}_{\mathrm{O}_{3}}$ points at faster ozone decay and thus a higher RP value. The reaction order of a species in a chemical reaction is generally a discrete and constant value in a formal kinetic analysis.
The ozone decomposition is however a complex radical chain mechanism. The total reaction order is merely an apparent reaction order and is not necessarily a discrete value: a summary of all relevant literature data has previously been presented by F. De Smedt et al. (2005). The magnitude of $\mathrm{n}$ varied from first-order $(\mathrm{n}=1)$ to second-order kinetics $(n=2)$. When the reaction order $n$ of ozone equals 1: Eq. [3] is valid. This equation was applied to analyze the ozone decomposition rate by Sotelo and Beltran (1987) and Sehested et al. (1991). When $\mathrm{n}$ equals 1.5 , a mathematical expression of the ozone decay is given by Eq. [4]:

$$
\begin{aligned}
& \ln \left[O_{3}\right]_{l i q, t}=\ln \left[O_{3}\right]_{l i q, 0}-k_{1} t \\
& \frac{1}{\sqrt{\left[O_{3}\right]_{l i q, t}}}=\frac{1}{\sqrt{\left[O_{3}\right]_{l i q, 0}}}+\frac{1}{2} k_{3 / 2} t
\end{aligned}
$$

However, this formal kinetic analysis with a discrete value of $\mathrm{n}$ is not always applicable, especially when chain reactions are at play. The real order of the decay rate can best be calculated in an alternative way by determining $\mathrm{r}_{\mathrm{O} 3}$ mathematically and directly from the slope of the ozone concentration profile as a function of the reaction time. By plotting $\ln \left(\mathrm{r}_{\mathrm{O}_{3}}\right)$ at time $\mathrm{t}$ as function of $\ln \left[\mathrm{O}_{3}\right]$ at this same time point $t$, the slope of the curve equals the order $n$. $\mathrm{k}_{\mathrm{n}}$ can be calculated from the intercept: Eq. [5]. This procedure is also followed by Gurol and Singer (1982) and they generally observed an order of about 2 with respect to ozone.

$$
\ln r_{O_{3}}=\ln k_{n}+n \ln \left[O_{3}\right]_{l i q}
$$

On our ozone decay profiles we performed a linear regression on the data of $\mathrm{n}$ as function of the $\mathrm{pH}$ (De Smedt et al., 2005). A slope $\Delta \mathrm{n} / \Delta \mathrm{pH}$ of $0.084 \pm 0.016$ for $293 \mathrm{~K}$ was determined, which indicated a clear $\mathrm{pH}$ dependence of $\mathrm{n}$. The order varied form 1.55 for $\mathrm{pH} 4$ to 2.11 for $\mathrm{pH} 11$. In our kinetic approach presented now, a formal kinetic analysis for $\mathrm{n}$ equals 1 and 1.5 was performed and results were compared to those obtained from Eq. [5].

The reaction orders and rate constants were then used to reconstruct the evolution of the ozone versus time concentration profiles and it was seen that visually no significant differences in the profiles could be noticed. Only the initial decay was sometimes not too well simulated. To compare the three different procedures, errors on rate constants and determination coefficients $R^{2}$ were determined to illustrate the quality of the kinetic analysis procedure. For pure water systems, the results are presented in Table 1a, $1 \mathrm{~b}$ and $1 \mathrm{c}$, for, respectively, $\mathrm{pH} 4.5$, 7.0 and 9.0. Rate constants $\mathrm{k}_{1}, \mathrm{k}_{1.5}$ and $\mathrm{n}$ and $\ln \left(\mathrm{k}_{\mathrm{n}}\right)$ with their errors and $\mathrm{R}^{2}$ are presented for several individual decays and for the pool of data for the different combined experiments at the same $\mathrm{pH}$. For the pooled data it was of 
TABLE 1. Comparison of the Formal and Alternative Kinetic Analysis Methods for the Ozone Decomposition in Pure Water

\begin{tabular}{|c|c|c|c|c|c|c|c|}
\hline & \multicolumn{2}{|l|}{ Order 1} & \multicolumn{2}{|l|}{ Order 1.5} & \multicolumn{3}{|c|}{ Alternative kinetic analysis } \\
\hline & $\mathrm{k}_{1}\left(\mathrm{~s}^{-1}\right)$ & $\mathrm{R}^{2}$ & $\mathrm{k}_{1.5}\left(\mathrm{~s}^{-1} \mathrm{M}^{-1 / 2}\right)$ & $\mathrm{R}^{2}$ & $\mathrm{n}$ & $\ln \left(\mathrm{k}_{\mathrm{n}}\right)$ & $\mathrm{R}^{2}$ \\
\hline Exp. 1 & $1.01 \times 10^{-4} \pm 1.17 \times 10^{-6}$ & 0.977 & $9.79 \times 10^{-3} \pm 5.94 \times 10^{-5}$ & 0.994 & $1.85 \pm 0.108$ & $10.2 \pm 0.977$ & 0.752 \\
\hline Exp. 2 & $1.30 \times 10^{-4} \pm 2.01 \times 10^{-6}$ & 0.975 & $1.26 \times 10^{-2} \pm 1.10 \times 10^{-4}$ & 0.991 & $1.96 \pm 0.098$ & $11.4 \pm 0.892$ & 0.816 \\
\hline Exp. 3 & $1.50 \times 10^{-4} \pm 2.22 \times 10^{-6}$ & 0.980 & $1.42 \times 10^{-2} \pm 1.17 \times 10^{-4}$ & 0.994 & $2.12 \pm 0.129$ & $12.9 \pm 1.18$ & 0.795 \\
\hline w.a. & $1.15 \times 10^{-4} \pm 3.22 \times 10^{-6}$ & & $1.07 \times 10^{-2} \pm 1.71 \times 10^{-4}$ & & & & \\
\hline \multicolumn{8}{|c|}{ b: $\mathrm{pH} 7.0$} \\
\hline Exp. 1 & $6.20 \times 10^{-4} \pm 7.77 \times 10^{-6}$ & 0.976 & $6.33 \times 10^{-2} \pm 4.58 \times 10^{-4}$ & 0.992 & $1.43 \pm 0.093$ & $-3.28 \pm 0.859$ & 0.710 \\
\hline Exp. 2 & $6.70 \times 10^{-4} \pm 1.15 \times 10^{-5}$ & 0.972 & $7.76 \times 10^{-2} \pm 3.22 \times 10^{-4}$ & 0.993 & $1.64 \pm 0.074$ & $-1.15 \pm 0.699$ & 0.851 \\
\hline Exp. 3 & $5.70 \times 10^{-4} \pm 1.02 \times 10^{-5}$ & 0.971 & $6.38 \times 10^{-2} \pm 6.42 \times 10^{-4}$ & 0.990 & $1.83 \pm 0.084$ & $0.459 \pm 0.793$ & 0.845 \\
\hline Exp. 1 & $3.45 \times 10^{-3} \pm 1.04 \times 10^{-4}$ & 0.919 & $9.61 \times 10^{-1} \pm 2.20 \times 10^{-2}$ & 0.952 & $1.76 \pm 0.137$ & $3.34 \pm 1.54$ & 0.753 \\
\hline Exp. 2 & $3.46 \times 10^{-3} \pm 9.99 \times 10^{-5}$ & 0.925 & $9.58 \times 10^{-1} \pm 1.97 \times 10^{-2}$ & 0.960 & $2.28 \pm 0.149$ & $9.07 \pm 1.66$ & 0.818 \\
\hline Exp 3 & $4.00 \times 10^{-3} \pm 1.01 \times 10^{-4}$ & 0.944 & $1.20 \pm 1.8 \times 10^{-2}$ & 0.977 & $1.92 \pm 0.123$ & $5.98 \pm 1.01$ & 0.721 \\
\hline pool & $3.50 \times 10^{-3} \pm 6.04 \times 10^{-5}$ & 0.896 & $9.86 \times 10^{-1} \pm 1.54 \times 10^{-2}$ & 0.913 & & & \\
\hline w.a. & $3.63 \times 10^{-3} \pm 1.76 \times 10^{-4}$ & & $1.06 \pm 3.46 \times 10^{-2}$ & & & & \\
\hline
\end{tabular}

Experimental conditions: $298 \mathrm{~K}$ a) $\mathrm{pH} 4.5$ and $\left[\mathrm{O}_{3}\right]_{\mathrm{i}}=2.0 \times 10^{-4} \mathrm{M}$; b) $\mathrm{pH} 7.0$ and $\left[\mathrm{O}_{3}\right]_{\mathrm{i}}=1.8 \times 10^{-4} \mathrm{M}$ and c) $\mathrm{pH} 9.0$ and $\left[\mathrm{O}_{3}\right]_{\mathrm{i}}=2.7 \times 10^{-5} \mathrm{M}$. $\mathrm{k}_{1}$ and $\mathrm{k}_{1.5}$ are, respectively, the reaction rate constants for the $1^{\text {st }}$ and $1.5^{\text {th }}$-order reaction approach. The alternative kinetic analysis method is performed according to Eq. [5]. $\mathrm{R}^{2}$ is the determination coefficient and w.a. the weighted average of rate constants.

course not possible to determine $\mathrm{n}$ and $\mathrm{k}_{\mathrm{n}}$ by the alternative kinetic analysis method.

From Table 1, one sees that both reaction order 1 and 1.5 yield rate constants $\mathrm{k}_{1}$ and $\mathrm{k}_{1.5}$ with statistical errors of the order of few percent. Pooling of the experimental results shows similar error ranges indicating no large systematic errors for the decays of these experiments. This is confirmed by the fact that the pooled values lie always within $10 \%$ of the weighted averages. When the sum of square of the residuals is compared for the two different formal kinetic methods, at $\mathrm{pH} 4$ the $1^{\text {st }}$ order is slightly better. When the order $\mathrm{n}$ calculated by the alternative kinetic analysis is reviewed, the values do not follow the earlier reported trends for 293 K (De Smedt et al., 2005).

Indeed large error margins on the derived values of $n$ and the extrapolated values of $\mathrm{k}_{\mathrm{n}}$ from experiment to experiment have also been observed in the past. At $\mathrm{pH} \mathrm{7,} \mathrm{there} \mathrm{is} \mathrm{not} \mathrm{really} \mathrm{a} \mathrm{difference} \mathrm{between} \mathrm{the} \mathrm{two}$ methods, but at $\mathrm{pH} 9$ there is a clear advantage towards the $1.5^{\text {th }}$ order. In all cases however, reaction order 1.5 gives a higher $\mathrm{R}^{2}$. The alternative kinetic analysis on the basis of the slope of the decay profiles (Eq. [5]) may theoretically give a more rigorous value for $\mathrm{n}$ for complex reaction systems. However its practical application for calculating the ozone steady-state concentrations $\left[\mathrm{O}_{3}\right]_{\text {liq,ss }}$ is not user friendly. Therefore in this study, reaction order 1.5 will be used for comparing $\mathrm{r}_{3}$ in the four investigated systems: pure water, phosphate buffered systems and AOPs by means of hydrogen peroxide.

\section{RESULTS AND DISCUSSION}

Three $\mathrm{pH}$ values were selected for studying the ozone decays in previously mentioned reaction conditions: slightly acidic $\mathrm{pH} 4.5$, neutral $\mathrm{pH} 7.0$ and alkaline $\mathrm{pH} 9.0$.

\section{Pure Water in the Absence of $\mathrm{H}_{2} \mathrm{O}_{2}$}

In Figure 2 an example of the ozone decay profiles as function of time is presented for the three different $\mathrm{pH}$ values.

In some experiments problems were encountered with the reproducibility. This can be explained by the fact that the $\mathrm{pH}$ of pure MilliQ water was only adjusted by means of p.a. reagents. Every impurity introduced in the system, by uncontrolled or uncontrollable circumstances, would immediately have a noticeable effect on the ozone decay 


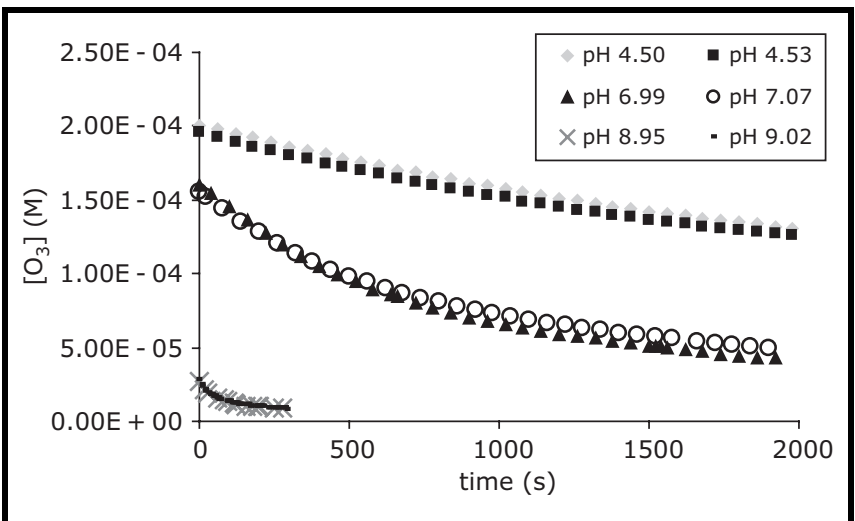

FIGURE 2. Ozone decay in pure water at $298 \mathrm{~K}$.

especially under acidic and neutral conditions. This same reproducibility problem was observed by Staehelin and Hoigné (1985). They observed that ozone decay rates at $\mathrm{pH}$ values lower than 8.0 could be disturbed by other processes such as wall effects.

However, Sehested et al. (1991) has tested the surface to volume ratio $\mathrm{S} / \mathrm{V}$ from 415 to $2175 \mathrm{~cm}^{2} \mathrm{~L}^{-1}$ and did not see any influence of this parameter on the ozone decay. This was confirmed by Lesko et al. (2004), who compared $\mathrm{S} / \mathrm{V}$ ratios of 2.06 up to $4.5 \mathrm{~cm}^{-1}$. Minchew et al. (1987) also point at another hypothesis that may explain problems with reproducibility. They found the $\mathrm{O}_{3}$ decay rate to be affected by the ozonation time. The longer ozone is bubbled through the solution, the faster ozone decomposes. This can be explained by the accumulation of decomposition products and organic contamination build up (De Smedt et al., 2001b) during the bubbling period.

Rate constants for these decays have already been presented in Table 1. When $1.5^{\text {th }}$ order rate constants of the ozone decay are compared, one sees an increase of a factor 6 from $\mathrm{pH} 4.5$ to $\mathrm{pH} 7.0$ and a factor 82 for $\mathrm{pH} 4.5$ to $\mathrm{pH}$ 9.0. Staehelin and Hoigne (1982) measured an increase of the rate constants of the ozone decomposition by a factor 10 per $\mathrm{pH}$ unit for alkaline $\mathrm{pH}$. We do not measure such a strong acceleration, since from $\mathrm{pH} 7.0$ to 9.0 the rate constant increases only by a factor of 15 . In literature, most studied systems are buffered or have higher ionic strengths or the ozone decays are determined in the presence of radical scavengers like $t$-butanol. A comparison of the literature data under more or less comparable experimental conditions with this work is presented in Table 2, where also the differences in experimental conditions are specified.

Looking at first-order rate constants $\mathrm{k}_{1}$ the agreement between the various authors is quite satisfactory. The higher value of $\mathrm{Ku}$ et al. (1996) can partially be explained by a somewhat higher $\mathrm{pH}$ of 5 in his experiment. For values of $\mathrm{k}_{1.5}$ calculated with expression given by $\mathrm{De}$ Smedt (2001a), the agreement is satisfactory except for
$\mathrm{pH}=9.0$. This can be explained by the fact the $1.5^{\text {th }}$ order rate constant at $\mathrm{pH}=9$ is an extrapolated value from a kinetic equation derived from experiments in the pH range 5.4 to 7.2. Hahn et al. (2000) found a $\mathrm{k}_{1}$ value comparable with ours in the acidic $\mathrm{pH}$ range. They also examined different experimental procedures for preparing ozone solutions to enhance reproducibility and concluded, as already mentioned, like Minchew et al. (1987), a dependency of the ozone decay rate on the ozonation time. For the data of $\mathrm{Ku}$ et al. (1996), the $\mathrm{k}_{1}$ rate constants are a factor of 2 to 3 higher than our data. However, there is a serious discrepancy in the reported $1^{\text {st }}$ - and $1.5^{\text {th }}$-order rate constants. The $1^{\text {st }}$-order rate constants point at much faster decays than the $1.5^{\text {th }}$ order. They also present an expression for the ozone loss rate $(\mathrm{M} / \mathrm{min})$ in the $\mathrm{pH}$ range of 2 to 10: Eq. [6].

$$
r_{O_{3}}=23.47\left[\mathrm{O}_{3}\right]^{1.5}\left[\mathrm{OH}^{-}\right]^{0.395}
$$

These initial ozone loss rates $(\mathrm{M} / \mathrm{s})$ are compared to those calculated for this work in Table 3 .

The values of $\mathrm{r}_{\mathrm{O} 3}$ calculated on the basis of Eq. [6] appear to be far too low compared to the present and earlier results of our lab. This can, of course, be expected as consequence of his very low values of the $1.5^{\text {th }}$-order rate constants leading to ozone decay rates that are inconsistent with the values that can be calculated from the rather high $1^{\text {st }}$-order rate constants.

In conclusion, it is seen that in pure water $1^{\text {st }}$-order ozone decay constants show a relatively good agreement between the various authors. In this way, comparable values or $\mathrm{r}_{\mathrm{O} 3}$ can be calculated. However since our data are better fitted with the $1.5^{\text {th }}$-order formalism, $1.5^{\text {th }}$ order rate constants will be used further in this work to quantify the effect of added phosphate and hydrogen peroxide.

\section{Pure Water in the Presence of $\mathrm{H}_{2} \mathrm{O}_{2}$}

As mentioned earlier, hydrogen peroxide acts as an initiator for the ozone decay. Most experimental data in literature are related to relatively high hydrogen peroxide concentrations of $10^{-3} \mathrm{M}$ and higher. It is general accepted that the reaction of ozone with $\mathrm{H}_{2} \mathrm{O}_{2}$ is slow and that the reaction with the ionized form $\mathrm{HO}_{2}^{-}$is responsible for the acceleration of the $\mathrm{O}_{3}$ decay. In this work, the influence of hydrogen peroxide was investigated for concentrations ranging from $10^{-7}$ to $10^{-5} \mathrm{M}$ for $\mathrm{pH}$ values 4.5 to 9.0 in solutions free of extra added radical scavengers. Only these low hydrogen peroxide concentrations were tested to assure the systems to be perturbed as less as possible. For industrial waste water treatment this is not a necessary condition, but for applications in the food industry, the preparation of drinking water and disinfection, it is crucial to introduce as low additive concentrations as possible. The goal is to examine in which $\mathrm{H}_{2} \mathrm{O}_{2}$ concentration window one sees a 
TABLE 2. Comparison of 1 st- and $1.5^{\text {th }}$-Order Rate Constants for Ozone Decay in Pure Water at pH 4.5, 7.0 and 9.0 at $298 \mathrm{~K}$. For This Work Pooled and Weighted Average (w.a.) Rate Constants are Given

\begin{tabular}{|c|c|c|c|c|c|c|}
\hline & \multicolumn{2}{|c|}{$\mathrm{pH} 4.5$} & \multicolumn{2}{|c|}{ pH 7} & \multicolumn{2}{|c|}{ pH 9} \\
\hline & $\mathrm{k}_{1}\left(\mathrm{~s}^{-1}\right)$ & $\mathrm{k}_{1.5}\left(\mathrm{~s}^{-1} \mathrm{M}^{-1 / 2}\right)$ & $\mathrm{k}_{1}\left(\mathrm{~s}^{-1}\right)$ & $\mathrm{k}_{1.5}\left(\mathrm{~s}^{-1} \mathrm{M}^{-1 / 2}\right)$ & $\mathrm{k}_{1}\left(\mathrm{~s}^{-1}\right)$ & $\mathrm{k}_{1.5}\left(\mathrm{~s}^{-1} \mathrm{M}^{-1 / 2}\right)$ \\
\hline This work $^{(a)}$ & $1.30 \times 10^{-4}$ & $1.19 \times 10^{-2}$ & $6.30 \times 10^{-4}$ & $6.99 \times 10^{-2}$ & $3.50 \times 10^{-3}$ & $9.86 \times 10^{-1}$ \\
\hline pooled w.a. & $1.22 \times 10^{-4}$ & $1.17 \times 10^{-2}$ & $6.21 \times 10^{-4}$ & $7.29 \times 10^{-2}$ & $3.77 \times 10^{-3}$ & 1.06 \\
\hline De Smedt $(2001 \mathrm{a})^{(\mathrm{b})}$ & & $1.20 \times 10^{-2}$ & & $6.54 \times 10^{-2}$ & & $2.56 \times 10^{-1}$ \\
\hline Hahn et al. $(2000)^{(\mathrm{c})}$ & $1.36 \times 10^{-4(\mathrm{~d})}$ & & & & & \\
\hline $\mathrm{Ku}$ et al. $(1996)^{(\mathrm{e})}$ & $3.83 \times 10^{-4(\mathrm{f})}$ & & $1.10 \times 10^{-3}$ & $6.50 \times 10^{-4}$ & $7.85 \times 10^{-3}$ & $3.93 \times 10^{-3}$ \\
\hline Sehested (1991) & $1.6 \times 10^{-4(\mathrm{~g})}$ & & & & & \\
\hline
\end{tabular}

(a) Experimental conditions: $298 \mathrm{~K}$; $\mathrm{pH} 4.5\left[\mathrm{O}_{3}\right]_{\mathrm{i}}=2.0 \times 10^{-4} \mathrm{M}$, pH $7.0\left[\mathrm{O}_{3}\right]_{\mathrm{i}}=1.8 \times 10^{-4} \mathrm{M}$ and $\mathrm{pH} 9.0\left[\mathrm{O}_{3}\right]_{\mathrm{i}}=2.8 \times 10^{-5} \mathrm{M}$ (b) calculated with the equation $\mathrm{k}_{1.5}=7.72\left[\mathrm{OH}^{-}\right]^{0.296}$, (c) ionic strength 0.1 (d) $\mathrm{pH} 4.1$ (e) discrepancy between values of $\mathrm{k}_{1}$ and $\mathrm{k}_{1.5}$.(f) $\mathrm{pH} 5.0$ (g) $\mathrm{pH} 4.0$ and $304 \mathrm{~K}$.

TABLE 3. Comparison of the Initial Ozone Loss Rate $\mathrm{r}_{\mathrm{O} 3}(\mathrm{M} / \mathrm{s})$ in Literature and this Work

\begin{tabular}{lcllc}
\hline pH & ${ }^{\left[\mathrm{O}_{3}\right]_{\text {liq }}}$ & $\begin{array}{c}\text { Ku et al. } \\
(1996)^{(\mathrm{a})}\end{array}$ & $\begin{array}{c}\text { De Smedt } \\
(2001 \mathrm{a})^{(\mathrm{b})}\end{array}$ & $\begin{array}{c}\text { This } \\
\text { work }^{(\mathrm{c})}\end{array}$ \\
\hline 4.5 & $2.0 \times 10^{-4}$ & $1.83 \times 10^{-10}$ & $3.35 \times 10^{-8}$ & $3.36 \times 10^{-8}$ \\
7.0 & $1.8 \times 10^{-4}$ & $1.61 \times 10^{-9}$ & $1.57 \times 10^{-7}$ & $1.76 \times 10^{-7}$ \\
9.0 & $2.8 \times 10^{-5}$ & $6.13 \times 10^{-10}$ & & $1.48 \times 10^{-7}$ \\
\hline
\end{tabular}

(a) Calculated with [6]; (b) calculated with the equation $\mathrm{r}_{\mathrm{O}_{3}}=7.72$ $\left[\mathrm{OH}^{-}\right]^{0.296}\left[\mathrm{O}_{3}\right]^{1.5}$ (c) $\mathrm{r}_{\mathrm{O} 3}=\mathrm{k}_{1.5}\left[\mathrm{O}_{3}\right]^{1.5}$, with $\mathrm{k}_{1.5}$ the w.a. of Table 2.

noticeable effect and where it can be useful for applying AOPs. In Table 4 , the $1.5^{\text {th }}$-order rate constants of the ozone decay for various hydrogen peroxide concentrations are presented for $\mathrm{pH}$ values 4.5, 7.0 and 9.0.

For $\mathrm{pH} 4.5$, there is an increase of the ozone decomposition rate constants when increasing amounts of hydrogen peroxide are added. Even for the lowest hydrogen peroxide concentration of $1.2 \times 10^{-7} \mathrm{M}$, an increase of $\mathrm{k}_{1.5}$ with a factor of 3 is seen with respect to pure water. Increasing $\mathrm{H}_{2} \mathrm{O}_{2}$ to $6.0 \times 10^{-6} \mathrm{M}$ or $1.2 \times 10^{-5}$ $\mathrm{M}$ makes the acceleration far more substantial; $\mathrm{k}_{1.5}$ increases respectively a factor 20 and 26. At $\mathrm{pH} 7.0$, the addition of $1.2 \times 10^{-7} \mathrm{M} \mathrm{H}_{2} \mathrm{O}_{2}$ does not affect the ozone decay constant, but, $6.0 \times 10^{-6} \mathrm{M}$ enhances the ozone decomposition rate constant with about a factor 10 . This means that at acidic and neutral $\mathrm{pH}$, AOPs can readily be achieved by adding very low amounts of hydrogen peroxide (below $10^{-5} \mathrm{M}$ ). At alkaline $\mathrm{pH}$, the ozone decay rate constant is already high and low concentrations of hydrogen peroxide do not induce much of an enhancement: one needs to go to hydrogen peroxide concentrations higher than $1 \times 10^{-5} \mathrm{M}$ to see an effect.

When comparing with literature data, it was found that all these experiments were carried out for higher hydrogen peroxide concentrations (Sehested et al., 1998;

TABLE 4. The $1.5^{\text {th }}$-Order Rate Constants for Ozone Decay in Pure Water as Function of the Hydrogen Peroxide Concentration at $\mathrm{pH} 4.5,7.0$ and 9.0 at $298 \mathrm{~K}$

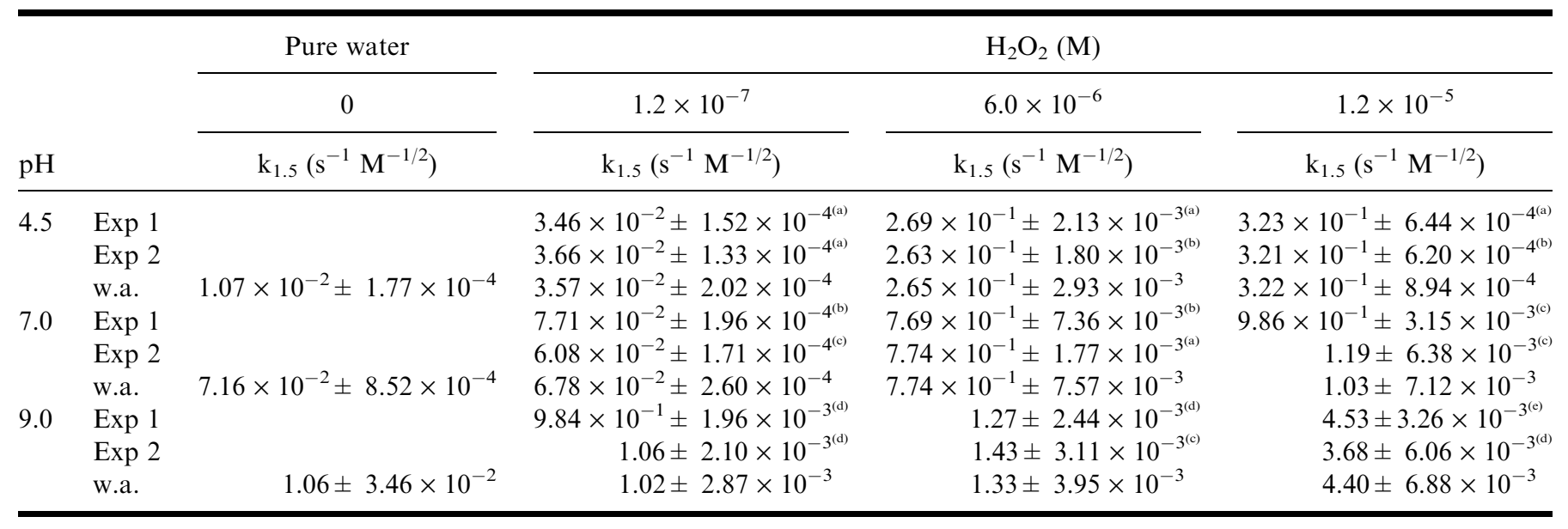

(a) $\left[\mathrm{O}_{3}\right]_{\mathrm{i}}=2.4 \times 10^{-4} \mathrm{M}$; (b) $\left[\mathrm{O}_{3}\right]_{\mathrm{i}}=2.0 \times 10^{-4} \mathrm{M}$; (c) $\left[\mathrm{O}_{3}\right]_{\mathrm{i}}=1.7 \times 10^{-4} \mathrm{M}$; (d) $\left[\mathrm{O}_{3}\right]_{\mathrm{i}}=1.6 \times 10^{-4} \mathrm{M}$; and (e) $\left[\mathrm{O}_{3}\right]_{\mathrm{i}}=1.5 \times 10^{-4} \mathrm{M}$. 
Kuo et al., 1999) or in systems spiked with radical scavengers (Staehelin and Hoigné, 1982). However, special attention should be paid to the elaborate kinetic and mechanistic study by Kuo et al. (1999), where the influence of hydrogen peroxide on the ozone decay rate has been investigated over a very broad concentration range. Since in their study the ratio of $\left[\mathrm{H}_{2} \mathrm{O}_{2}\right] /\left[\mathrm{O}_{3}\right]$ was much larger than 1, the $\mathrm{H}_{2} \mathrm{O}_{2}$ concentration remained constant during the entire ozone decay process. In this way the $\mathrm{H}_{2} \mathrm{O}_{2}$ concentration was equal to the initial concentration $\left[\mathrm{H}_{2} \mathrm{O}_{2}\right]_{0}$, which facilitates the formal kinetic analysis considerably.

It was concluded that the additional formation of hydroxyl radicals through the reactions with hydrogen peroxide only becomes significant when the hydrogen peroxide concentration is about $2 \times 10^{-4} \mathrm{M}$ or higher. Since under our experimental conditions the hydrogen peroxide concentration is at least a factor of 10 lower and the initial ratio $\left[\mathrm{H}_{2} \mathrm{O}_{2}\right] /\left[\mathrm{O}_{3}\right]$ is much smaller than 1 , the hydrogen peroxide concentration seriously drops during the ozone decays and a formal kinetic analysis of the hydrogen peroxide effect becomes unrealistic.

The effect of adding traces of $\mathrm{H}_{2} \mathrm{O}_{2}$ (below $10^{-5} \mathrm{M}$ ) to pure water systems can be summarized as follows: it is already possible to establish AOPs in the acidic and neutral $\mathrm{pH}$ range since ozone decay rates can be increased by at least a factor 10 . At alkaline $\mathrm{pH}$, due to the already fast decays, higher hydrogen peroxide concentrations are needed to realize AOPs and are not well applicable for pure water system applications. In any case this finding corroborates the conclusions of Kuo et al. (1999) that the peroxone process for the pollutant destruction will not be very favorable under very alkaline conditions.

\section{Phosphate-Buffered Water in the Absence of $\mathrm{H}_{2} \mathrm{O}_{2}$}

It was seen in previous experiments (Table 1 and Table 4) that quite large variation of the order of $20 \%$ could be measured between $\mathrm{k}_{1.5}$ values obtained from the experiments at fixed $\mathrm{pH}$. One of the causes was poor $\mathrm{pH}$ stability, especially at neutral $\mathrm{pH}$. Therefore buffer systems and more specifically phosphate buffers were introduced and tested on their effect on the reproducibility. Another reason for checking phosphate containing systems is the fact that phosphate is a known radical scavenger. In this way, one may expect that the value of $\mathrm{r}_{\mathrm{O} 3}$ may decrease and higher $\left[\mathrm{O}_{3}\right]_{\text {liq }}$ could be achieved: Eq. [1].

Furthermore with phosphate, it is possible to cover the whole $\mathrm{pH}$ range with the same buffer components and a similar ionic strength could be achieved at $\mathrm{pH}$ 4.5, 7.0 and 9.0. Buffer concentrations were kept as low as possible to eliminate interfering factors like ionic strength, impurities, etc. Various buffer concentrations between 0.005 and $0.02 \mathrm{M}$ were tested, but no significant effect of the concentration on the ozone decay rate constants was observed. For the systematic tests, concentrations of $0.01 \mathrm{M}$ for $\mathrm{pH} 7.0$ and 9.0 and $0.02 \mathrm{M}$ for $\mathrm{pH} 4.5$ were chosen and all have an ionic strength $\mathrm{I}$ of 0.02 . The $1.5^{\text {th }}$-order rate constants of ozone in phosphate buffered systems are presented in Table 5.

First, one sees that the difference between the rate constants of various experiments in these phosphatebuffered systems did not become smaller compared to the pure systems and the expected stabilization of the radical chain mechanism was not realized. But more important, a rather unexpected kinetic behavior of ozone is observed. When the $1.5^{\text {th }}$-order rate constants are compared with the pure water results a very pronounced acceleration is noticed. For $\mathrm{pH} 4.5,7.0$ and 9.0 an increase by (respectively) a factor of about 5, 8 and 2 was measured

The measured increase of the ozone decay rate by phosphate in pure water systems is, at first sight, contradictory to literature data. Phosphate is generally known to be a radical scavenger, which will react slowly with radicals like the hydroxyl radical and thus slows down the chain reaction mechanism (Staehelin and Hoigne, 1985). In Table 6 a comparison is made between the literature data and our work in terms of ozone loss rate $\mathrm{r}_{\mathrm{O} 3}(\mathrm{M} / \mathrm{s})$ instead of the rate constants, to avoid discussions on the reaction order. It is clear that almost all the $\mathrm{r}_{\mathrm{O} 3}$ 's calculated from our decays are higher than those reported in literature.

Gurol and Singer (1982) investigated the effect of phosphate on ozone decays and observed a decrease of decay rate with increasing phosphate concentration.

TABLE 5. The $1.5^{\text {th }}$-Order Rate Constants for Ozone Decay in Phosphate- Buffered Systems

\begin{tabular}{llrc}
\hline $\mathrm{pH}$ & & $\mathrm{k}_{1.5}\left(\mathrm{~s}^{-1} \mathrm{M}^{-1 / 2}\right)$ & {$\left[\mathrm{O}_{3}\right]_{\mathrm{i}}$} \\
\hline 4.5 & Exp 1 & $6.54 \times 10^{-2} \pm 9.54 \times 10^{-5}$ & $2.31 \times 10^{-4}$ \\
& Exp 2 & $7.12 \times 10^{-2} \pm 6.66 \times 10^{-5}$ & $2.15 \times 10^{-4}$ \\
& Exp 3 & $4.88 \times 10^{-2} \pm 1.97 \times 10^{-5}$ & $2.17 \times 10^{-4}$ \\
& Exp 4 & $5.40 \times 10^{-2} \pm 1.01 \times 10^{-4}$ & $1.95 \times 10^{-4}$ \\
& w.a & $5.13 \times 10^{-2} \pm 1.55 \times 10^{-5}$ & \\
7.0 & Exp 1 & $5.44 \times 10^{-1} \pm 3.21 \times 10^{-3}$ & $2.23 \times 10^{-4}$ \\
& Exp 2 & $5.28 \times 10^{-1} \pm 6.52 \times 10^{-4}$ & $1.58 \times 10^{-4}$ \\
& Exp 3 & $6.06 \times 10^{-1} \pm 1.23 \times 10^{-3}$ & $1.79 \times 10^{-4}$ \\
& Exp 4 & $6.72 \times 10^{-1} \pm 2.09 \times 10^{-3}$ & $1.78 \times 10^{-4}$ \\
& w.a. & $5.54 \times 10^{-1} \pm 4.08 \times 10^{-3}$ & \\
9.0 & Exp 1 & $1.59 \pm 1.77 \times 10^{-3}$ & $5.27 \times 10^{-5}$ \\
& Exp 2 & $1.73 \pm 3.19 \times 10^{-3}$ & $3.81 \times 10^{-5}$ \\
& Exp 3 & $1.97 \pm 4.25 \times 10^{-3}$ & $3.98 \times 10^{-5}$ \\
& Exp 4 & $2.20 \pm 2.09 \times 10^{-3}$ & $4.11 \times 10^{-5}$ \\
& w.a. & $1.84 \pm 5.98 \times 10^{-3}$ & \\
\hline
\end{tabular}

At $\mathrm{pH} 4.5,7.0$ and 9.0 at $298 \mathrm{~K}$ with buffer concentrations of $0.02 \mathrm{M}$ at $\mathrm{pH} 4$ and $0.01 \mathrm{M}$ at $\mathrm{pH} 7.0$ and 9.0, ionic strength of 0.02 . w.a. is the weighted average of $\mathrm{k}_{1.5}$ of the decays. 
TABLE 6. Comparison Between $\mathrm{r}_{\mathrm{O} 3}(\mathrm{M} / \mathrm{s})$ Calculated from Literature Data and Our Work for Phosphate-Buffered Systems

\begin{tabular}{|c|c|c|c|}
\hline $\mathrm{pH}$ & 4.5 & 7.0 & 9.0 \\
\hline this work $^{(a)}$ & \multicolumn{3}{|c|}{$1.50 \times 10^{-7} 1.35 \times 10^{-6} 5.70 \times 10^{-7}$} \\
\hline Gurol et al. (1982) $)^{(\mathrm{b})}$ & \multicolumn{3}{|c|}{$7.99 \times 10^{-9} 1.22 \times 10^{-7} 7.99 \times 10^{-8}$} \\
\hline Sotelo et al. $(1987)^{(\mathrm{c})}$ & \multicolumn{3}{|c|}{$7.00 \times 10^{-8} 1.08 \times 10^{-7} 1.58 \times 10^{-7}$} \\
\hline Roth et al. (1983) (d) & \multicolumn{3}{|c|}{$1.39 \times 10^{-7} 1.66 \times 10^{-7} 1.04 \times 10^{-7}$} \\
\hline $\begin{array}{l}\text { Westerhoff } \\
\text { et al. (1997) }\end{array}$ & \multicolumn{3}{|c|}{$7.92 \times 10^{-7}$} \\
\hline
\end{tabular}

(a) $\mathrm{r}_{\mathrm{O}_{3}}=\mathrm{k}_{1.5}\left[\mathrm{O}_{3}\right]^{1.5}$ with $\mathrm{k}_{1.5}$ the weighted average of Table 5, (b) $\mathrm{I}=0.1$ and $\mathrm{r}_{\mathrm{O}_{3}}=\mathrm{k}_{\mathrm{d}}\left[\mathrm{O}_{3}\right]^{2}\left(\mathrm{k}_{\mathrm{d}}=\right.$ equation [7]), (c) $\mathrm{I}=0.15$ (d) $\mathrm{I}=0.1$ (e) $\left[\mathrm{PO}_{4}\right]_{\text {tot }}$ $=0.001 \mathrm{M}$ and $\mathrm{pH} 7.5, \mathrm{I}=0.003$. Experimental conditions: $298 \mathrm{~K}, \mathrm{pH} 4.5$ and $\left[\mathrm{O}_{3}\right]_{\mathrm{i}}=2.0 \times 10^{-4} \mathrm{M}, \mathrm{pH} 7.0$ and $\left[\mathrm{O}_{3}\right]_{\mathrm{i}}=1.8 \times 10^{-4} \mathrm{M}$ and $\mathrm{pH} 9.0$ and $\left[\mathrm{O}_{3}\right]_{\mathrm{i}}=4.5 \times 10^{-5} \mathrm{M}$ and $\mathrm{I}=0.02$.

However a comparison with pure systems was not made. They derived Eq. [7] for the second-order decay constant $\mathrm{k}_{\mathrm{d}}$ for ozone in phosphate-buffered systems with ionic strength $\mathrm{I}=0.1$.

$$
k_{d}=(1.4 \pm 0.4) \times 10^{4}\left[O H^{-}\right]^{0.51 \pm 0.17}
$$

Values of $\mathrm{r}_{\mathrm{O} 3}$ in our experiments are about factor 10 larger, but the difference is getting smaller at higher $\mathrm{pH}$. They also present an equation of $\mathrm{k}_{\mathrm{d}}$ at ionic strength $\mathrm{I}=$ 1.0. At this ionic strength calculated $\mathrm{k}_{\mathrm{d}} \mathrm{s}$ are about a factor 20 smaller than those at $I=0.1$. Sotelo et al. (1987) did measurements in phosphate-buffered solutions with ionic strength of 0.15 . Their $\mathrm{r}_{\mathrm{O} 3}$ values are also lower than ours. The same trends are seen for the $\mathrm{r}_{\mathrm{O} 3}$ values derived by Roth and Sullivan (1983) for ionic strength 0.1 , except for $\mathrm{pH} 4$, were $\mathrm{r}_{\mathrm{O} 3}$ is in good agreement with our value.

Discrepancies between these calculated $\mathrm{r}_{\mathrm{O} 3}$ values and our experimental ones can possibly be explained by our much lower ionic strength. Westerhoff et al. (1997) worked at a lower ionic strength $\mathrm{I}=0.003$ at neutral $\mathrm{pH}$ and these $\mathrm{r}_{\mathrm{O} 3}$ values are indeed higher, which confirms this hypothesis. Finally Bezbarua and Reckhow (2004) found that at neutral $\mathrm{pH}$ and in the presence of $t$-butanol, phosphate has minimal effect as radical scavenger. Possibly low phosphate concentrations have initially an accelerating effect on the ozone decay, but when the concentrations increase, the effect reverses and phosphate slows down the decay (Vandersmissen et al., in preparation). It should be mentioned here that we have checked that these experimental results are simulated well by a slightly modified HEA (Hoigné et al.) model (Hoigne and Bader, 1976; Buhler et al., 1984; Staehelin et al., 1984; Virdis et al., 1995). We have called it the LPAC-model (Laboratory for Physical and Analytical Chemistry) and the details are described in the $\mathrm{PhD}$ thesis of Vandersmissen (2008).
Also, in the presence of DOM, phosphate can cause an acceleration of the ozone decay rate. Staehelin and Hoigné (1985) state that when $\mathrm{H}_{2} \mathrm{PO}_{4}^{-}$reacts with $\mathrm{OH}$ radicals, the formed secondary radical $\mathrm{HPO}_{4}^{-}$is able to abstract a $\mathrm{H}$ atom from organic compounds. For example, this is an abstraction of an $\mathrm{H}$ atom standing in $\alpha$ position to the alcoholic group in alcohols. Via this reaction, phosphate could interfere with the radical-type chain reaction and even act as a secondary promoter and accelerate the ozone decay. Westerhoff et al. (1997) state that concentrations of $0.2 \mathrm{mg} / \mathrm{L} \mathrm{DOM}$, which is below detection limits of our TOC analysis, can react with the $\mathrm{OH}$ radical and this may cause noticeable retardation of the ozone decay rate in pure water systems. In the presence of phosphate however, $\mathrm{OH}$ radicals will preferentially react with the buffer species present in much higher concentrations than the DOM. In an indirect way DOM leads than to an acceleration of the ozone decays.

Thus, it should be concluded that low concentration of phosphate rather accelerates the ozone decays. In this way $\mathrm{r}_{\mathrm{O} 3}$ increases and the $\left[\mathrm{O}_{3}\right]_{\text {liq,ss }}$ will be lower in the presence of traces of phosphate. Indirect oxidation paths will be enhanced while the direct oxidation processes will be inhibited.

\section{Phosphate-Buffered Water in the Presence of $\mathrm{H}_{2} \mathrm{O}_{2}$}

The effect of $\mathrm{H}_{2} \mathrm{O}_{2}$ on the ozone decay rate constants in phosphate buffered systems is shown in Table 7. First let us compare $\mathrm{k}_{1.5}$ with the buffered systems without hydrogen peroxide. One sees that except for acidic conditions at $1.2 \times 10^{-5} \mathrm{M} \mathrm{H}_{2} \mathrm{O}_{2}$, the addition of $\mathrm{H}_{2} \mathrm{O}_{2}$ does not accelerate the ozone decay rate. This means that in the presence of a phosphate buffer even at very low ionic strength, no additional AOP effect can be realized by adding small amounts of hydrogen peroxide. Compared to ultrapure water systems only a marginal increase in $\mathrm{k}_{1.5}$ can be seen at $\mathrm{H}_{2} \mathrm{O}_{2}$ concentrations of $1.2 \times 10^{-7} \mathrm{M}$. Higher $\mathrm{H}_{2} \mathrm{O}_{2}$ concentrations increase $\mathrm{k}_{1.5}$ about a factor 5 at $\mathrm{pH} 7$ but the effect levels off at $\mathrm{pH}$ 9. To a large extent it can be concluded from these results that realizing AOPs by addition of small amounts of $\mathrm{H}_{2} \mathrm{O}_{2}$ (below $10^{-5} \mathrm{M}$ ) is not quite feasible in phosphate-buffered systems except around $\mathrm{pH} 7$.

From a mechanistic point, it looks that phosphate ions trigger the chain propagation mechanism and in this way mask the efficiency of $\mathrm{H}_{2} \mathrm{O}_{2}$ as a radical promoter. Staehelin and Hoigné (1982) have also examined the influence of hydrogen peroxide on the ozone decay in phosphate-buffered waters. But they added radical scavengers, so rate constants cannot be compared. They found that the consumption of $\mathrm{HO}_{2}^{-}$is rapidly compensated by the dissolved $\mathrm{H}_{2} \mathrm{O}_{2}$ and the half-life time of hydrogen peroxide decreases at high $\mathrm{pH}$ values. At $\mathrm{pH} 8$ and ozone concentrations of $10^{-4} \mathrm{M}$, the half-life time of $\mathrm{H}_{2} \mathrm{O}_{2}$ drops to 100 seconds. 
TABLE 7. The $1.5^{\text {th }}$-Order Rate Constants for Ozone Decay in Phosphate Buffered Water in the Presence of Various Concentrations of Hydrogen Peroxide at $\mathrm{pH} 4.5 ; 7.0$ and 9.0 at $298 \mathrm{~K}$ and $\mathrm{I}=0.02$

\begin{tabular}{|c|c|c|c|c|}
\hline \multirow[b]{3}{*}{$\mathrm{pH}$} & & \multicolumn{3}{|c|}{$\mathrm{H}_{2} \mathrm{O}_{2}(\mathrm{M})$} \\
\hline & & $1.2 \times 10^{-7}$ & $6.0 \times 10^{-6}$ & $1.2 \times 10^{-5}$ \\
\hline & & $\mathrm{k}_{1.5}\left(\mathrm{~s}^{-1} \mathrm{M}^{-1 / 2}\right)$ & $\mathrm{k}_{1.5}\left(\mathrm{~s}^{-1} \mathrm{M}^{-1 / 2}\right)$ & $\mathrm{k}_{1.5}\left(\mathrm{~s}^{-1} \mathrm{M}^{-1 / 2}\right)$ \\
\hline \multirow[t]{4}{*}{4.5} & Exp 1 & $2.10 \times 10^{-2} \pm 9.68 \times 10^{-5^{(a)}}$ & $7.26 \times 10^{-2} \pm 1.10 \times 10^{-4^{(\mathrm{d})}}$ & $1.18 \times 10^{-1} \pm 5.64 \times 10^{-4^{(a)}}$ \\
\hline & Exp 2 & $1.60 \times 10^{-2} \pm 1.80 \times 10^{-5^{(e)}}$ & $8.74 \times 10^{-2} \pm 2.26 \times 10^{-4^{(e)}}$ & $9.90 \times 10^{-2} \pm 4.78 \times 10^{-4^{(b)}}$ \\
\hline & Exp 3 & $1.98 \times 10^{-2} \pm 4.50 \times 10^{-5^{(c)}}$ & $7.20 \times 10^{-2} \pm 1.85 \times 10^{-4^{(f)}}$ & $1.33 \times 10^{-1} \pm 1.88 \times 10^{-3^{(c)}}$ \\
\hline & w.a. & $1.66 \times 10^{-2} \pm 1.10 \times 10^{-4}$ & $7.47 \times 10^{-2} \pm 3.12 \times 10^{-4}$ & $1.08 \times 10^{-1} \pm 2.02 \times 10^{-3}$ \\
\hline \multirow[t]{4}{*}{7.0} & Exp 1 & $1.90 \times 10^{-1} \pm 6.04 \times 10^{-4^{(a)}}$ & $3.84 \times 10^{-1} \pm 2.32 \times 10^{-3^{(b)}}$ & $4.18 \times 10^{-1} \pm 2.81 \times 10^{-3^{(b)}}$ \\
\hline & $\operatorname{Exp} 2$ & $1.89 \times 10^{-1} \pm 5.86 \times 10^{-4^{(c)}}$ & $2.69 \times 10^{-1} \pm 1.48 \times 10^{-3^{(a)}}$ & $2.50 \times 10^{-1} \pm 1.19 \times 10^{-3^{(1)}}$ \\
\hline & Exp 3 & $2.22 \times 10^{-1} \pm 1.08 \times 10^{-3^{(1)}}$ & $4.25 \times 10^{-1} \pm 2.35 \times 10^{-3^{(1)}}$ & $3.00 \times 10^{-1} \pm 2.79 \times 10^{-3^{(1)}}$ \\
\hline & w.a. & $1.94 \times 10^{-1} \pm 1.73 \times 10^{-3}$ & $3.30 \times 10^{-1} \pm 3.62 \times 10^{-3}$ & $4.13 \times 10^{-1} \pm 2.79 \times 10^{-3}$ \\
\hline \multirow[t]{4}{*}{9.0} & Exp 1 & $1.71 \pm 2.92 \times 10^{-3^{(\mathrm{h})}}$ & $1.78 \pm 5.22 \times 10^{-3^{(g)}}$ & $1.99 \pm 2.65 \times 10^{-3^{(\mathrm{g})}}$ \\
\hline & Exp 2 & $1.69 \pm 3.07 \times 10^{-3^{(g)}}$ & $1.69 \pm 2.45 \times 10^{-3^{(h)}}$ & $2.05 \pm 4.05 \times 10^{-3^{(\mathrm{g})}}$ \\
\hline & Exp 3 & $2.24 \pm 4.51 \times 10^{-3^{(\mathrm{h})}}$ & $1.61 \pm 3.34 \times 10^{-3^{(g)}}$ & $1.86 \pm 8.40 \times 10^{-4^{(\mathrm{h})}}$ \\
\hline & w.a. & $1.80 \pm 6.19 \times 10^{-3}$ & $1.65 \pm 6.66 \times 10^{-3}$ & $1.90 \pm 4.91 \times 10^{-3}$ \\
\hline
\end{tabular}

(a) $\left[\mathrm{O}_{3}\right]_{\mathrm{i}}=1.8 \times 10^{-4} \mathrm{M}$, (b) $\left[\mathrm{O}_{3}\right]_{\mathrm{i}}=2.0 \times 10^{-4} \mathrm{M}$, (c) $\left[\mathrm{O}_{3}\right]_{\mathrm{i}}=1.0 \times 10^{-4} \mathrm{M},(\mathrm{d})\left[\mathrm{O}_{3}\right]_{\mathrm{i}}=3.0 \times 10^{-4} \mathrm{M},(\mathrm{e})\left[\mathrm{O}_{3}\right]_{\mathrm{i}}=2.5 \times 10^{-4} \mathrm{M},(\mathrm{f})\left[\mathrm{O}_{3}\right]_{\mathrm{i}}=1.5 \times$ $10^{-4} \mathrm{M},(\mathrm{g})\left[\mathrm{O}_{3}\right]_{\mathrm{i}}=6.0 \times 10^{-5} \mathrm{M}$ and $(\mathrm{h})\left[\mathrm{O}_{3}\right]_{\mathrm{i}}=5.0 \times 10^{-5} \mathrm{M}$.

\section{CONCLUSIONS}

The goal of this study was to determine ozone decay rates $\mathrm{r}_{\mathrm{O} 3}$ in acidic, neutral and alkaline conditions. These ozone reaction rates are needed to calculate the maximum achievable $\left[\mathrm{O}_{3}\right]_{\text {liq,ss }}$ for practical applications. First various kinetic formalisms to describe the ozone decay were checked and compared. It is concluded that in the $\mathrm{pH}$ range from 4.5 to 9.0 a $1.5^{\text {th }}$-reaction order simulates the ozone decay profiles quite well. Pooling the experimental decay profiles yields rate constants comparable to the weighted average values. By adding concentrations of hydrogen peroxide below $1 \times 10^{-5} \mathrm{M}$ to pure water systems, it is already possible to realize AOP's in the acidic and neutral $\mathrm{pH}$ range.

Ozone decay rates can be increased, relative to the pure systems, by at least a factor 10 through the addition of as little as $6.0 \times 10^{-6} \mathrm{M} \mathrm{H}_{2} \mathrm{O}_{2}$. Due to the already fast ozone decays at alkaline $\mathrm{pH}$, much higher hydrogen peroxide concentrations will be needed to see an AOP effect. To enhance reproducibility of these experiments, low concentration phosphate buffers are added to the pure systems. In contradiction with most literature data, these phosphate buffers seem to induce an acceleration of the ozone decay rate. This can either be explained by an acceleration caused by phosphate or by a retardation of the ozone decay rate in pure water due to very low concentrations of DOM. Finally it seems almost impossible to establish AOPs by adding low concentrations of hydrogen peroxide to these phosphate-buffered solutions except at neutral $\mathrm{pH}$. In further work, we will study how far the ozone steady state concentration $\left[\mathrm{O}_{3}\right]_{\mathrm{liq}, \mathrm{ss}}$ will be influenced by the addition of these small amounts of phosphate and hydrogen peroxide as a function of the mass transfer coefficient $\mathrm{k}_{\mathrm{L}} \mathrm{a}$ and the partial ozone pressure $\mathrm{P}_{\mathrm{O} 3}$ in the gas phase.

\section{ACKNOWLEDGMENTS}

$\mathrm{K}$. Vandersmissen acknowledges the financial support of the FWO-Vlaanderen.

\section{REFERENCES}

Acero, J.L. and U. Von Gunten, "Influence of Carbonate on the Ozone/ Hydrogen Peroxide based Advanced Oxidation Process for Drinking Water Treatment", Ozone Sci. Eng., 22:305-328 (2000).

Alfassi, Z.B., R.E. Huie, M. Kumar, and P. Neta, "TemperatureDependence of the Rate Constants for Oxidation of OrganicCompounds by Peroxyl Radicals in Aqueous Alcohol-Solutions", J. Phys. Chem., 96:767-770 (1992).

Bezbarua, B.K. and D.A. Reckhow, "Modification of the Standard Neutral Ozone Decomposition Model”, Ozone Sci. Eng., 26:345-357 (2004).

Buhler, R.E., J. Staehelin, and J. Hoigné, "Ozone Decomposition in Water Studied by Pulse-Radiolysis. $1 . \mathrm{HO}_{2} / \mathrm{O}_{2}^{-}$and $\mathrm{HO}_{3} / \mathrm{O}_{3}^{-}$As Intermediates", J. Phys. Chem., 88:2560-2564 (1984).

Buxton, G.V., C.L. Greenstock, W.P. Helman, and A.B. Ross, "CriticalReview of Rate Constants for Reactions of Hydrated Electrons, Hydrogen-Atoms and Hydroxyl Radicals $\left(\mathrm{OH} / \mathrm{O}^{-}\right)$in AqueousSolution", J. Phys. Chem. Ref. Data, 17:513-886 (1988).

De Smedt, F. "Fundamental Study of the Behavior of Ozone in Water", PhD thesis, Faculty of Science, KULeuven 2001a.

De Smedt, F., S. De Gendt, M. M. Heyns, and C. Vinckier, "Materials Compatibility and Organic Build-up During Ozone-Based Cleaning of Semiconductor Devices", Solid State Phenomena, 66-67:63-66 (2001b). 
De Smedt, F., H. Vankerckhoven, K. Vandersmissen, and C. Vinckier, "The $\mathrm{O}_{3}$ Stability Near Neutral $\mathrm{pH}$ in Pure Processes and Rinse Water", $17^{\text {th }}$ International Ozone Congress, Strasbourg. IX 2.2; 2005.

Elovitz, M.S., U. Von Gunten, and H.P. Kaiser, "Hydroxyl Radical/ Ozone ratios during Ozonation Processes. II. The Effect of Temperature, pH, Alkalinity, and DOM Properties", Ozone Sci. Eng., 22:123-150 (2000).

Glaze, W.H., J.W. Kang, and D.H. Chapin, "The Chemistry of WaterTreatment Processes Involving Ozone, Hydrogen-Peroxide and Ultraviolet-Radiation", Ozone Sci, Eng. 9:335-352 (1987).

Gurol, M.D. and P.C. Singer, "Kinetics of Ozone Decomposition-A Dynamic Approach”, Environ. Sci. Technol., 16:377-383 (1982).

Hahn, J., G. Lachmann, and J.J. Pienaar, "Kinetics and Simulation of the Decomposition of Ozone in Acidic Aqueous Solutions", S. Afr. J. Chem.-Suid-Afrikaanse Tydskrif Vir Chemie, 53:132-138 (2000).

Hoigné, J. and H. Bader, "Role of Hydroxyl Radical Reactions in Ozonation Processes in Aqueous-Solutions", Water Res., 10:377-386 (1976).

Hoigné, J. and H. Bader, "Rate Constants of Reactions of Ozone with Organic and Inorganic-Compounds in Water. 1. Non-Dissociating Organic-Compounds”, Water Res., 17:173-183 (1983a).

Hoigné, J. and H. Bader, "Rate Constants of Reactions of Ozone with Organic and Inorganic-Compounds in Water. 2. Dissociating Organic-Compounds", Water Res., 17:185-194 (1983b).

Hoigné, J., H. Bader, W.R. Haag, and J. Staehelin, "Rate Constants of Reactions of Ozone with Organic and Inorganic-Compounds in Water. 3. Inorganic-Compounds and Radicals", Water Res., 19:993-1004(1985).

Kruithof, J.C. and W.J. Masschelein,."State-of-the-Art of the Application of Ozonation in BENELUX Drinking Water Treatment", Ozone Sci. Eng., 21:139-152 (1999).

$\mathrm{Ku}, \mathrm{Y}$. , W.J. Su, and Y.S. Shen, "Decomposition Kinetics of Ozone in Aqueous Solution", Indust. Eng. Chem. Res., 35:3369-3374 (1996).

Kuo, C.H., L. Zhong, M.E. Zappi, and A.P. Hong, "Kinetics and Mechanism of the Reaction between Ozone and Hydrogen Peroxide in Aqueous Solutions", Can. J. Chem. Eng., 77:473-482 (1999).

Lesko, T.M., A.J. Colussi, and M.R. Hoffmann, "Hydrogen Isotope Effects and Mechanism of Aqueous Ozone and Peroxone Decompositions", J. Amer. Chem. Soc., 126:4432-4436 (2004).

Loeb, B.L., "Ozone: Science \& Engineering —-The first 23 years", Ozone Sci. Eng. 24: 399-412 (2002).

Lowndes, R. "State of the Art for Ozone UK Experience", Ozone Sci. Eng. 1999; 21:201-205.

Matsumoto, N. and K. Watanabe, "Foot Prints and Future Steps of Ozone Applications in Japan”, Ozone Sci. Eng., 21:127-138 (1999).
Minchew, E.P., J.P. Gould, and F.M. Saunders, "Multistage Decomposition Kinetics of Ozone in Dilute Aqueous-Solutions", Ozone Sci. Eng., 9:165-177 (1987).

Perkowski, J., L. Kos, and S. Ledakowicz, "Advanced Oxidation of Textile Wastewaters", Ozone Sci. Eng., 22:535-550 (2000).

Roth, J.A. and D.E. Sullivan, "Kinetics of Ozone Decomposition in Water", Ozone Sci. Eng., 5:37-49 (1983).

Sehested, K., H. Corfitzen, J. Holcman, C.H. Fischer, and E.J. Hart, "The Primary Reaction in the Decomposition of Ozone in Acidic Aqueous-Solutions", Environ. Sci. Technol., 25:1589-1595 (1991).

Sehested, K., H. Corfitzen, J. Holcman, and E.J. Hart, "On the Mechanism of the Decomposition of Acidic $\mathrm{O}_{3}$ Solutions, Thermally or $\mathrm{H}_{2} \mathrm{O}_{2}$-initiated", J. Phys. Chem. A 102:2667-2672 (1998).

Sotelo, J.L., F.J. Beltran, F.J. Benitez, and J. Beltranheredia, "Ozone Decomposition in Water - Kinetic-Study", Indust. Eng. Chem. Res., 26:39-43 (1987).

Staehelin, J., R.E. Buhler, and J. Hoigné, "Ozone Decomposition in Water Studied by Pulse-Radiolysis. 2. $\mathrm{OH}$ and $\mathrm{HO}_{4}$ As Chain Intermediates", J. Phys. Chem. 88:5999-6004 (1984).

Staehelin, J. and J. Hoigné, "Decomposition of Ozone in Water - Rate of Initiation by Hydroxide Ions and Hydrogen-Peroxide", Environ. Sci. Technol., 16:676-681 (1982).

Staehelin, J. and J. Hoigné, "Decomposition of Ozone in Water in the Presence of Organic Solutes Acting As Promoters and Inhibitors of Radical Chain Reactions", Environ. Sci. Technol., 19:1206-1213 (1985).

Stemmler, K. and U. Von Gunten, "OH Radical-Initiated Oxidation of Organic Compounds in Atmospheric Water Phases: Part 1. Reactions of Peroxyl Radicals derived from 2-Butoxyethanol in Water”, Atmos. Environ., 34:4241-4252 (2000).

Vandersmissen, K., "Advanced Oxidation Processes in Ozonated Water Systems: an Experimental and Theoretical Study", PhD-thesis, Faculty of Science, KULeuven 2008.

Vandersmissen, K., F. De Smedt, and C. Vinckier, manuscript in preparation 2008.

Virdis, A., A. Viola, and G. Cao, "A Novel Kinetic Mechanism of Aqueous-Phase Ozone Decomposition”, Ann. Chim., 85:633-647 (1995).

Weinstein, J. and B.H.J. Bielski, "Kinetics of the Interaction of $\mathrm{HO}_{2}$ and $\mathrm{O}_{2}^{-}$Radicals with Hydrogen-Peroxide-Haber-Weiss Reaction", J. Amer. Chem. Soc., 101:58-62 (1979).

Westerhoff, P., R. Song, G. Amy, and R. Minear, "Applications of Ozone Decomposition Models”, Ozone Sci. Eng., 19:55-73 (1997). 